Pak. J. Agri., Agril. Engg., Vet. Sci., 2021, 37 (2): 71-78

ISSN: 1023-1072 (Print), ISSN: 2663-7863 (Online)

https://doi.org/10.47432/2021.37.2.1

\title{
IMPACT OF VARIOUS PRESERVATIVE SOLUTIONS ON VASE LIFE AND POST-HARVEST QUALITY OF CUT ROSES
}

\author{
M. M. Aziz ${ }^{1}$, S. Rashid ${ }^{1}$, H. Kousar ${ }^{2}$, R. Hussain ${ }^{3}$ and T. Saeed ${ }^{4}$ \\ ${ }^{1}$ Horticultural Research Institute, Ayub Agricultural Research Institute, Faisalabad, Pakistan \\ ${ }^{2}$ Food Technology Section, Post-harvest Research Center, Ayub Agricultural Research Institute, \\ Faisalabad, Pakistan \\ ${ }^{3}$ Department of Horticultural Sciences, The Islamia University of Bahawalpur, Punjab, Pakistan \\ ${ }^{4}$ Floriculture Research Sub-Station, Ayub Agricultural Research Institute, Faisalabad, Pakistan
}

\begin{abstract}
Short vase life and post-harvest losses of cut flowers are major threat to floriculture industry. There are different preservative solutions that have been used to extend the post-harvest life of cut flowers. Hence, this study was executed at Floriculture laboratory of Ayub Agricultural Research Institute, Faisalabad during 2018-2020 to explore the efficacy of different preservative solutions on vase life and post-harvest quality of cut roses. There were 6 treatments viz, ( $T_{1}=$ Distilled water, $T_{2}=$ Silver nitrate @ 100 ppm, $T_{3}=8$-Hydroxyquiroline citrate @ 100 ppm, $T_{4}=$ Sodium thiosulphate @100 ppm, $T_{5}=$ Sodium benzoate @100 ppm, $T_{6}=$ Sucrose @ $40 \mathrm{~g} / \mathrm{L}$ ) and two rose cultivars Kardinal and Gold medal. The experiment was arranged according to complete randomized design (CRD). Results designated that longest vase life ( 15 days), maximum soluble solid contents ( 9.3 Brix) and longest opening period (7.4 days) were acquired with silver nitrate @100 ppm solution while maximum flower size $\left(6.77 \mathrm{~cm}^{2}\right)$ and largest head diameter $(8.6 \mathrm{~cm})$ were achieved with sodium thiosulphate when applied at the rate of 100 $\mathrm{ppm}$ in cultivar Kardinal. All other chemical solutions also displayed positive effects. Keeping in view the remarkable impact of Silver nitrate on vase life and quality of cut roses, it is recommended for commercial growers and cut flower industry for preservation of cut roses for longer time.
\end{abstract}

Keywords: cut roses, floriculture, kardinal, silver nitrate, vase life

\section{INTRODUCTION}

Roses (Rosa hybrida L.) belongs to family "Rosaceae" and Genus "Rosa" which holds almost 150 species as well as 1400 cultivars. Roses holds superiority over other flowers as these are being used extensively for ornamental purposes and are highly valued for its beauty, delicate nature, charisma and fragrance (Hassen and Yassin, 2013). In interior beautification, cut rose flowers has an imperative role and enhance charm to various occasions like marriage ceremonies, arrival and departure of personages, as a sign of compassion, birthdays gifts and Valentine's Day etc. Moreover, roses play a dynamic part in the manufacturing of numerous products of nutritional and medicinal importance. Roses are extremely valued for economical profits as these are source of best raw material which is used in agro-based industry particularly in the perfumery

"Corresponding author: sahar_rasheed25@yahoo.com and cosmetics. Though, a very peculiar side of rose production is to acquire the cut flowers which significantly deals with the floriculture trade. Roses are undoubtedly the most cherished flowers due to their ornamental and marketable values. Roses play a significant role in beautification of our surroundings as well as gardens with the same comfy colors and rich aromas. Roses are most economically cut flowers in the world (Suong et al., 2017).

In Pakistan, admiration and uses of cut roses in daily life is growing with improvement of aesthetic sense of people. One can notice many flower shops at well-known shopping and trading centers selling cut flowers in various forms such as Bracelets, Crowns and Bouquets etc. These flower products are commonly used by women and young girls on different occasions. Rose bouquets are generally presented to others to express the best wishes. Cut roses are very delicate in nature. Almost 20 percent of fresh flowers loses their quality during post-harvest 
handling and a large portion of remaining flowers marketed with poor quality dissatisfying the consumer due to pathological and physiological issues during handling (Panhwar, 2006). Flowers can remain fresh for 2-3 days under ambient environment but mostly people like to relish the flower beauty and appearance for a longer period. Due to the increasing demand of cut roses in Pakistan, there is a dire need of vase life extension and post-harvest maintenance of cut flowers (Tsegaw et al., 2011; Zamani et al., 2011).

Floriculture industry is growing now a days in both developed and developing countries. But this sector has some restraints. Post-harvest losses are the key problem of horticulture industry in general and floriculture sector in particular. Cut flowers short life is linked with wilting, vascular blockage via air and microbes and ethylene production (Elgimabi, 2011). Preservative solutions are usually requisite as energy source, decrease bacterial build up as well as vascular blockage, enhance water uptake of stem and stop the adverse influence of ethylene (Nigussie, 2005). To extend the vase life of cut flowers, incorporation of different preservatives in vase solution is highly recommended (Ichimura et al., 2006). The quality and longevity of cut flowers also depends on the ambient atmosphere. The most deleterious effect on cut flowers is triggered by ethylene. Some adverse effects of ethylene comprise of yellowing of leaf, flower or petal drop, irregular opening of flower and premature death. Due to diverse impacts of ethylene on different plant species, it should be highly valuable to curtail ethylene effects during postharvest life of cut flowers. However, there are various preservative solutions available to prolong the post-harvest life of cut rose thus enhancing the value for longer period (Reezi et al., 2009).

Currently information concerning the effect of different preservative solutions on vase life of cut roses is scanty in Pakistan. More over various chemical compounds were evaluated previously for preservation of plants and increasing vase life which have side effects for environment. While preservative solutions in our experiment are good and safe antibacterial tool for ornamental and horticultural products. Keeping in view the emerging demand and socio-economic value of cut roses, this trial was conducted to inspect the prospects and potential of different preservative solutions for extension of cut roses post-harvest life.

\section{MATERIALS AND METHODS Plant material}

This research was carried out at laboratory of Floriculture Research Sub Station, Ayub Agricultural Research Institute, Faisalabad, Pakistan (longitude $=73^{\circ}-09^{\prime} \mathrm{E}$, latitude $=31^{\circ}$ $42^{\prime} \mathrm{N}$, Altitude $=189 \mathrm{~m}$ ) during 2019-2020 in the month of March-April to assess the efficacy of different chemical/ preservatives on vase life of rose cultivars Kardinal and Gold medal. Flowers of both cultivars were harvested at tight bud stage from field area of floriculture and carried to laboratory instantly. The stem of both flower cultivars was trimmed at height of $15 \mathrm{~cm}$ having one or two foliage leaves.

\section{Experimental design and treatments}

Cut flower were washed with distilled water and immersed in already prepared solutions of following preservatives:

$\mathrm{T}_{1}=$ Distilled water

$\mathrm{T}_{2}=$ Silver nitrate $(100 \mathrm{ppm})$

$\mathrm{T}_{3}=8$-Hydroxyquiroline citrate (100 ppm)

$\mathrm{T}_{4}=$ Sodium thiosulphate ppm (100 ppm)

$\mathrm{T}_{5}=$ Sodium benzoate $\mathrm{ppm}(100 \mathrm{ppm})$

$\mathrm{T}_{6}=$ Sucrose $(40 \mathrm{~g} / \mathrm{Liter})$

After pulsing treatment with these preservatives, the flowering stems of both cultivars were taken out and shifted to distilled water and kept under observation throughout the experiment period at room temperature with 60 $70 \%$ relative humidity and maintained through humidifier. The experiment was conducted according to Complete Randomized Design with 5 treatments and 3 replications.

\section{Parameters to be taken Vase life (days)}

For longevity/vase life of flowers, total numbers of days were counted from placement of flower in preservative solution to losses its decorative value (Suong et al., 2017).

\section{Opening period of flower (days)}

For complete opening of flower, total numbers of days were counted from placement of flower in preservative solution to unfolding of sepals.

\section{Size of flower $\left(\mathrm{cm}^{2}\right)$}

Size of flower was determined by using Vernier caliper after fully opening of petals.

\section{Flower head diameter (cm)}

Flower head diameter was measured with the help of Vernier caliper. 


\section{Flower fresh weight (g)}

Flower fresh weight of each sample was calculated with the help of digital balance (SF400A, China).

Flower dry weight (g)

Flowers of each sample were dried in oven at $60^{\circ} \mathrm{C}$ for 72 hours and weight was measured with the help of digital balance (SF-400A, China) (Kalayeh et al., 2011).

\section{Total soluble solids (Brix)}

For determination of total soluble solids, tissue sap of petals was extracted and placed drops of juice on prism surface of refractometer (BX-1, Atago, Japan) and reading was noted.

\section{Solution uptake $(\mathrm{ml} / \mathrm{g})$}

Solution uptake of each sample was calculated by using following formula by (Chamani et al., 2005).

Solution uptake $=S(t-1)-\frac{\text { st }}{\text { Initial fresh wt }} \times 100$

Here st- 1 solution weight of control, st $=$ weight of solution

\section{Statistical analysis}

Data was analyzed statistically using software Statistix and significance difference test was done using LSD at 5\% probability level (Stewel et al., 1997).

\section{RESULTS AND DISCUSSION Vase life (days)}

The vase life of both flower cultivars was significantly influenced by different chemicals/ preservatives (Figure 1). No interaction effect was noted among both varieties and chemicals as longest vase life (15 days) was recorded with silver nitrate @100 ppm solution in cultivar kardinal followed by glucose with (13.47 days) @100 ppm solution, 8, hydroxyquioline with 13.37 days at $100 \mathrm{ppm}$ solution in kardinal cultivar. Sodium thiosulphate and sodium benzoate also enhanced vase life of cut flowers significantly up to 12.03 and 11.93 days respectively. Lowest vase life (5 days) was recorded in control treatment. Vase life of cut flowers is affected by various factors like respiration rate, disease inoculation, carbohydrates deterioration, solution/water uptake. Ethylene synthesis has a key role in senescence during vase life of cut flowers. Likewise, carbohydrates and sugars are also helpful in quality maintenance of cut flowers for longer duration (Hassen and Yassin, 2013). Silver nitrate and sodium thiosulphate have been using as potent ethylene inhibitors in plant tissues hence, the vase life of cut roses might be increased due to treatment with these chemicals which decreased the ethylene production and also involved in antimicrobial activity in plant tissues hence manifested beneficial effect in extending their longevity (Malakar et al, 2019). Sucrose being a carbohydrate is also involved in extension of vase life and increased water absorption through inhibiting vascular blockage. Singh et al. (2002) also observed extension in vase life of cut roses with use of various chemicals. The results of (Mahmoud et al., 2014) also support this research who suggested that vase life can be extended by application of silver nitrate (30 ppm), 8, HQS (100 ppm) and sucrose $(3 \%)$ by minimizing ethylene production and growth of micro-organisms as well as improving solution absorbance. (Skutnik et al., 2020) described in their study that 8, hydroxyquioline citrate enhance vase of cut flowers.

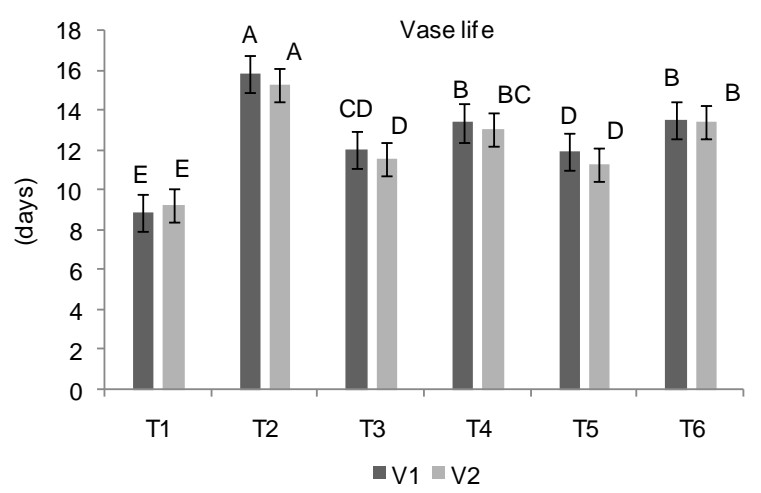

Figure 1. Effect of different preservative solutions on vase life of cut rose cultivars (Kardinal and Gold medal)

Here, $\mathrm{V}_{1}=$ Kardinal, $\mathrm{V}_{2}=$ Gold medal; $\mathrm{T}_{1}=$ Distilled water, $\mathrm{T}_{2}=$ Silver nitrate, $\mathrm{T}_{3}=8$-Hydroxyquiroline citrate, $\mathrm{T}_{4}=$ Sodium thiosulphate, $T_{5}=$ Sodium benzoate, $T_{6}=$ Sucrose

\section{Opening period of flower (days)}

Opening period of Flower has significantly influenced by different chemical solution as described in (Figure 2). Longest opening period (7.4 days) was achieved by silver nitrate in cultivar kardinal followed by 8 , hydroxyquioline ( 6 days), sodium thiosulphate (5.7 days) and sodium benzoate ( 5 days) respectively in gold medal cultivar. Control treatment stood lowest in relation to opening period of flowers. Silver nitrate most effectively enhanced the opening period of flower. This might be due to its capability to inhibit the ethylene production 
which ultimately enhanced opening period and vase life of flower (Hassen and Yassin, 2013). The wide antimicrobial effect of silver nitrate is well-known, since $\mathrm{Ag}+$ ions replace the hydrogen cations $(\mathrm{H}+)$ of sulfhydryl or thiol groups (- $\mathrm{SH})$ on surface proteins in cell membranes of bacteria, which leads to loss of membrane integrity and causing cell death. Silver nanoparticles have higher surface area to volume ratio compared with other silver forms which may make it more effective as a biocide. The 8, HQS being antimicrobial was effective to suppress bacterial population and early wilting of flowers which leads to increased flower opening and also increases water uptake by reducing physiological stem blockage (Kader et al., 2017). Sedaghathoor et al. (2020) stated that opening period of flower, wilting percentage and vase life of chrysanthemum was enhanced by application of silver thisulphate in vase solution.

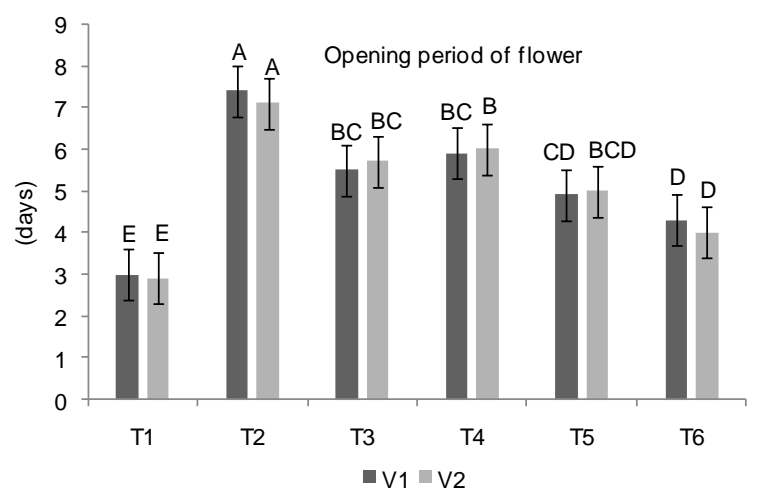

Figure 2. Effect of different preservative solutions on opening period of flower (days) of cut rose cultivars Kardinal and Gold medal. $\left(\mathrm{V}_{1}=\right.$ Kardinal, $\mathrm{V}_{2}=$ Gold medal; $\mathrm{T}_{1}=$ Distilled water, $T_{2}=$ Silver nitrate, $T_{3}=8$-Hydroxyquiroline citrate, $T_{4}=$ Sodium thiosulphate, $T_{5}=$ Sodium benzoate, $T_{6}=$ Sucrose)

\section{Size of flower $\left(\mathrm{cm}^{2}\right)$}

All the preservative solutions have significant impact on flower size of both cultivars. However, no interaction effect was noted among flower cultivars and chemicals (Figure 3 ). Maximum flower size $\left(6.77 \mathrm{~cm}^{2}\right)$ was acquired with sodium thiosulphate when applied at the rate of 100 ppm in kardinal cultivar. The 8 , hydroxyquioline stood $2^{\text {nd }}$ in terms of flower size $\left(5.87 \mathrm{~cm}^{2}\right)$. All other chemical treatments remained best in terms of enhancement of flower size of both cultivars as compared to control. Control gave smallest flower size $\left(3.33 \mathrm{~cm}^{2}\right)$ among all treatments recorded in cultivar kardinal. This could be due to the treatment of cut roses with different preservative solutions which inhibited ethylene production, minimized weight loss, enhanced diameter, suppressed bacterial growth and enhanced vase life which ultimately improved flower size. These results are in line with previous findings of Bhattacharjee, (1999) who described that Sugar such as glucose, lactose, sucrose and maltose exhibited maximum vase life, highest flower diameter and better water absorption of cut rose "Happiness". Besides flower diameter fresh as well as dry weight also improved. Sikandar et al. (2012) also illustrated that maximum size $\left(6.62 \mathrm{~cm}^{2}\right)$ was attained with application of $25 \mathrm{ppm}$ sodium thiosulphate and $7.5 \%$ sucrose solution (6.63 $\mathrm{cm}^{2}$ ) in cut rose cultivar Kardinal.

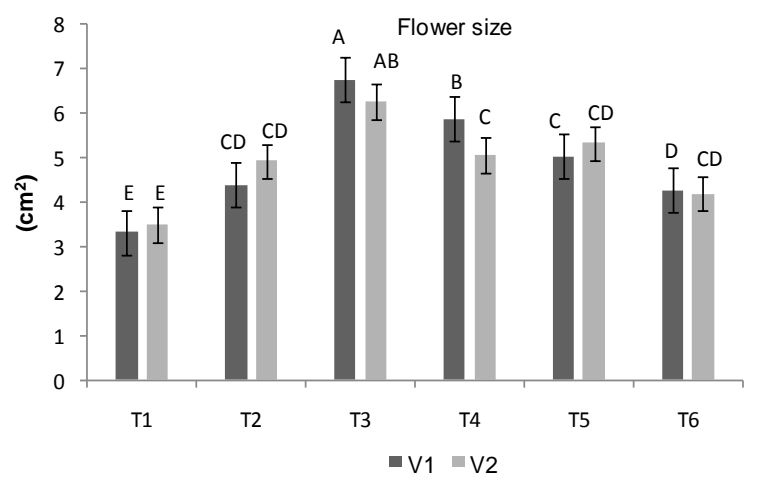

Figure 3. Effect of different preservative solutions on flower size of cut rose cultivars Kardinal and Gold medal. ( $\mathrm{V}_{\mathrm{l}}=$ Kardinal, $\mathrm{V}_{2}=$ Gold medal; $\mathrm{T}_{1}=$ Distilled water, $\mathrm{T}_{2}=$ Silver nitrate, $T_{3}=8$-Hydroxyquiroline citrate, $T_{4}=$ Sodium thiosulphate, $T_{5}=$ Sodium benzoate, $T_{6}=$ Sucrose)

\section{Flower head diameter $(\mathrm{cm})$}

Different chemical solutions imparted significant impression on flower head diameter in kardinal and gold medal cut roses as explained in (Figure 4). Largest head diameter $(8.6 \mathrm{~cm})$ was recorded in cultivar Kardinal when treated with sodium thiosulphate followed by 8 , hydroxyquioline with $(8.2 \mathrm{~cm})$ diameter, sodium benzoate $(7.4 \mathrm{~cm})$ and glucose $(6.9 \mathrm{~cm})$ diameter in cut roses kardinal and Gold medal respectively. Smallest head diameter $(5.7 \mathrm{~cm})$ was observed in control treated with distilled water in cut rose gold medal. This increment in head diameter might be due to the effect of chemicals by improving solution and water uptake, reducing flower weight loss and minimizing microbial population. Another reason in flower diameter enhancement could be variation in genetic makeup of flowers These results are confirmatory with (Ichimura et al., 2002) where increment in head diameter of cut roses were observed with application of $20 \mathrm{~g}$ of sucrose +200 mg of HQS solutions. Similarly, 
(Ichimura et al., 2005) also found that head diameters of flower cultivars Delilah and Sonia were increased with application of same treatment. (Chaudhary and Khanal, 2018) also reported previously that flower diameter was increased with application of sucrose solution on cut roses.

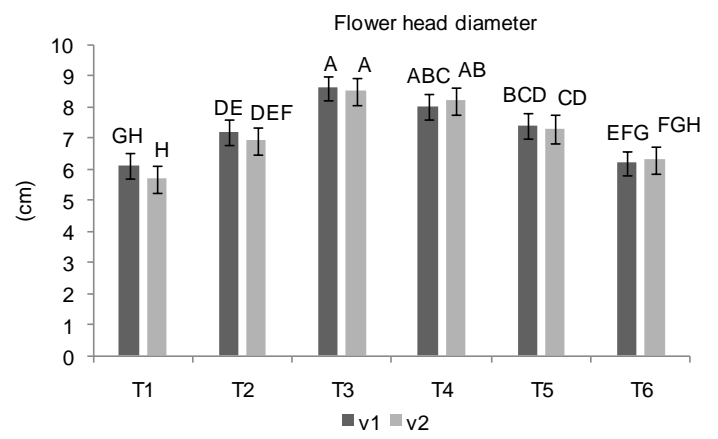

Figure 4. Effect of different preservative solutions on head diameter of cut rose cultivars Kardinal and Gold medal $\left(\mathrm{V}_{1}=\right.$ Kardinal, $\mathrm{V}_{2}=$ Gold medal; $\mathrm{T}_{1}=$ Distilled water, $\mathrm{T}_{2}=$ Silver nitrate, $T_{3}=8$-Hydroxyquiroline citrate, $T_{4}=$ Sodium thiosulphate, $T_{5}=$ Sodium benzoate, $T_{6}=$ Sucrose)

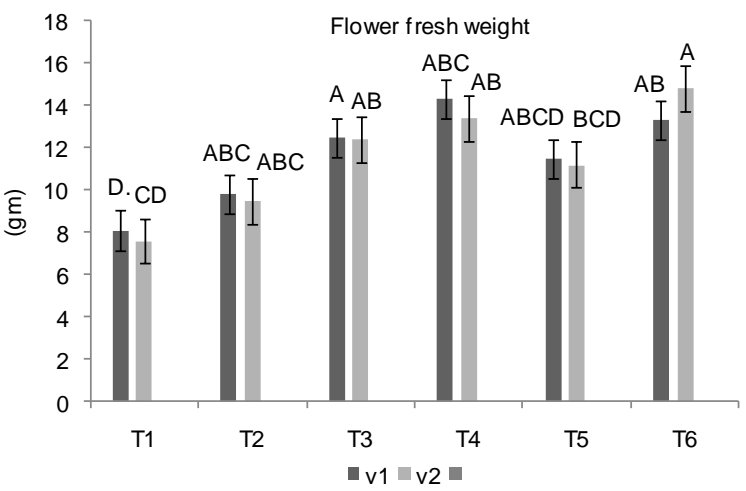

Figure 5. Effect of different preservative solutions on flower fresh weight of cut rose cultivars Kardinal and Gold medal $\left(\mathrm{V}_{1}=\right.$ Kardinal, $\mathrm{V}_{2}=$ Gold medal; $\mathrm{T}_{1}=$ Distilled water, $\mathrm{T}_{2}=$ Silver nitrate, $T_{3}=8$-Hydroxyquiroline citrate, $T_{4}=$ Sodium thiosulphate, $T_{5}=$ Sodium benzoate, $T_{6}=$ Sucrose)

\section{Flower fresh weight (gm)}

Different preservative solutions have highly significant effects on flower fresh weight of cut roses kardinal and gold medal as illustrated in (Figure 5). Highest fresh weight $(14.8 \mathrm{gm})$ was recorded in cultivar gold medal after treatment of glucose @ $40 \mathrm{~g} / \mathrm{L}$ followed by $14.3 \mathrm{gm}$ in kardinal and $13.4 \mathrm{gm}$ in gold medal roses after application of Sodium thiosulphate @100 ppm. Minimum fresh weight of flower $(7.6 \mathrm{gm})$ was noted in control treatment. The increment in fresh weight might be due to the more solution uptake during the initial storage time as reinforced by Seyf et al. (2012) who observed aluminum treated rose cultivar "Boeing" had higher fresh weight than control due to more water and solution absorption, reduction in water loss and less microbial population loads. This research is confirmatory with previous findings of Tsegaw et al. (2011) who found increment in fresh weight of cut flowers treated with HQS. (Hajizadeh et al., 2012) stated that fresh weight of flowers showed decreasing trend during vase life in rose cultivar Black magic.

\section{Flower dry weight (gm)}

All the chemical solutions imparted significant impact on dry weight of both cultivars (Figure 6). Maximum dry weight $(4.1 \mathrm{gm})$ was observed in gold medal cultivar when treated with glucose @ $40 \mathrm{~g} / \mathrm{L}$ while minimum dry weight $(2.8 \mathrm{gm})$ was noted in control treatment. All other treatments have superiority over control. This might be due to the significance of sucrose for cell growth and dry mater accumulation as it can help to the endogenous sucrose to act as substrate of respiration as illustrated by Dineshbabu et al. (2002). Our results are in line with previous findings of (Awan et al., 2017) where increment in flower size and dry weight was noted after application of sucrose solution.

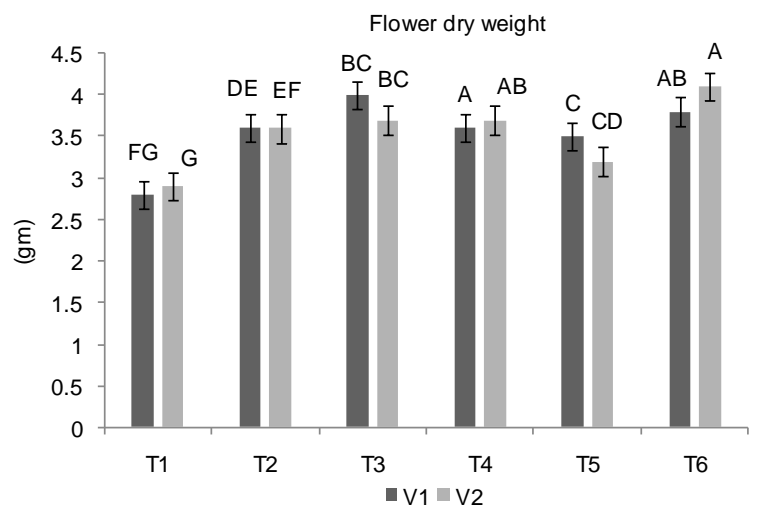

Figure 6. Effect of different preservative solutions on flower dry weight of cut rose cultivars Kardinal and Gold medal ( $\mathrm{V}_{1}=$ Kardinal, $\mathrm{V}_{2}=$ Gold medal; $\mathrm{T}_{1}=$ Distilled water, $\mathrm{T}_{2}=$ Silver nitrate, $T_{3}=8$-Hydroxyquiroline citrate, $T_{4}=$ Sodium thiosulphate, $T_{5}=$ Sodium benzoate, $T_{6}=$ Sucrose)

\section{Total soluble solids (Brix)}

Total soluble solids of cut rose cultivars Kardinal and Gold medal was significantly influenced by all treatments presented in (Figure 7). Highest soluble solids (9.3 Brix) were recorded in kardinal flower after treatment of silver nitrate preservative at $100 \mathrm{ppm}$ level while lowest 
soluble solids (6.4 Brix) were obtained in control treatment. Rest of the chemicals exhibited the significance supremacy over control in terms of soluble solids. The soluble solids contents have significant role in provision of energy source to petals of flowers in order to maintain turgor pressure as well as in flower opening (Ichimura et al., 2005). Suong et al. (2017) had described in his study that flowers having long vase life had comparatively higher soluble solids describing that the internal sucrose might be imperative for providing the energy essential for the nourishment of vase life. Our results are in favor with previous findings of Tsegaw et al. (2011) who observed highest soluble solids in cultivar "Red calypso" while lowest in cultivar "Akito" and intermediate in "Viva" cultivar. Previously Elgimabi and Sliai (2013) noticed in their study that soluble solids contents were increased during start of the study while decreased at the end.

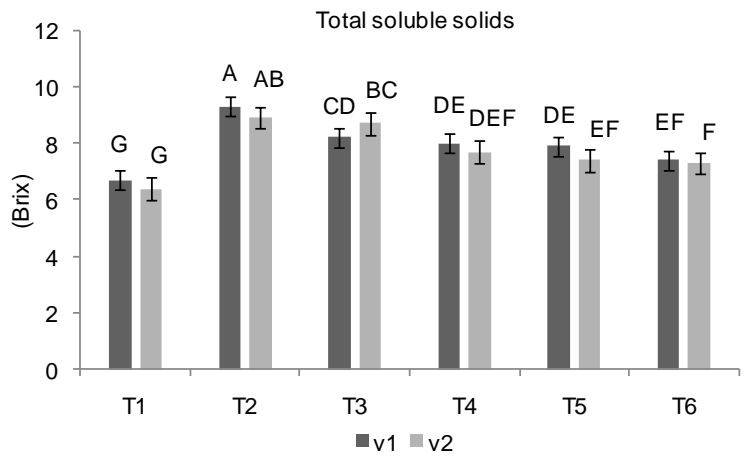

Figure 7. Effect of different preservative solutions on total soluble solids of cut rose cultivars Kardinal and Gold medal $\left(\mathrm{V}_{1}=\right.$ Kardinal, $\mathrm{V}_{2}=$ Gold medal; $\mathrm{T}_{1}=$ Distilled water, $\mathrm{T}_{2}=$ Silver nitrate, $\mathrm{T}_{3}=8$-Hydroxyquiroline citrate, $\mathrm{T}_{4}=$ Sodium thiosulphate, $T_{5}=$ Sodium benzoate, $T_{6}=$ Sucrose)

\section{Solution uptake $(\mathrm{ml} / \mathrm{g})$}

Data concerning solution uptake of flower cultivars kardinal and gold medal was significantly affected by various chemical solutions (Figure 8 ). Maximum solution uptake $(0.32 \mathrm{ml} / \mathrm{g})$ was recorded in gold medal cultivar when treated with sodium benzoate @100 ppm solution. Sodium thiosulphate occupied the $2^{\text {nd }}$ position with solution uptake of $0.30 \mathrm{ml} / \mathrm{g}$ in gold medal cultivar. Rest of the treatments also got superiority over control treatment in relation to solution uptake in both cultivars of cut roses. Vase solution contamination is one of main constraint for cut roses vase life. This microbial population growth reduced water absorption rate triggered by xylem plugging and ultimately causes early flower wilting (Macnish et al.,
2008). It is evident that bacterial multiplication in vase solution lessens the vase life of cut flowers (Liao et al., 2001). In the current study silver nitrate, sodium thiosulphate, sodium benzoate and 8 , hydroxiquioline were effective in inhibition of microbial growth due to antimicrobial properties, reduced vascular blockage, resulting in maximum solution uptake and enhancement in cut roses vase life. Our results are in line with previous findings of Knee, (2000) who observed variation in solution uptake rate in different cut flowers and witnessed that "Red Sky" cultivar exhibited a higher capability to absorb solution as compared to the cultivar "Blizzard" which could be due to more positive response to the chemical solutions. Likewise, (Sudaira et al., 2017) also practiced similar findings in cut roses previously. Kinfe et al. (2018) observed increase in solution uptake in rose cultivar "top secret" with application of sucrose and hydroxiquioline preservative solutions.

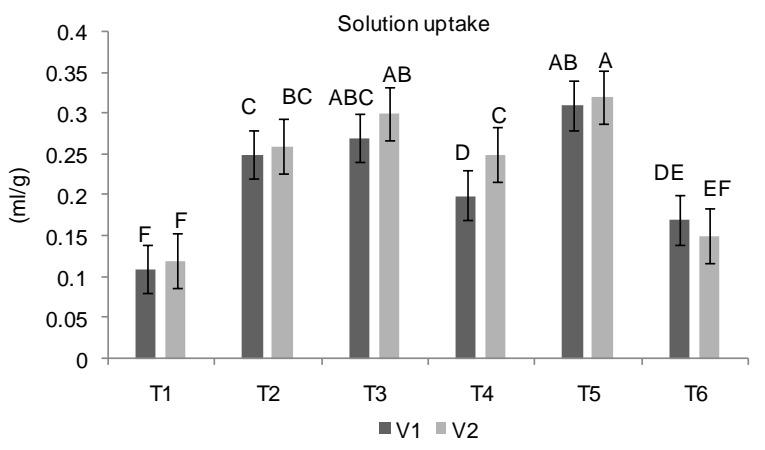

Figure 8. Effect of different preservative solutions on total solution uptake of cut rose cultivars Kardinal and Gold medal $\left(\mathrm{V}_{1}=\right.$ Kardinal, $\mathrm{V}_{2}=$ Gold medal; $\mathrm{T}_{1}=$ Distilled water, $\mathrm{T}_{2}=$ Silver nitrate, $T_{3}=8$-Hydroxyquiroline citrate, $T_{4}=$ Sodium thiosulphate, $T_{5}=$ Sodium benzoate, $T_{6}=$ Sucrose)

\section{CONCLUSION}

It is concluded that selected chemicals have significant impact on vase life extension and improvement in post-harvest life of cut roses. Treatment with silver nitrate exhibited longer vase life, acquired maximum soluble solids contents and largest opening period in rose cultivar Kardinal while maximum size of rose and head diameter was obtained with sodium thiosulphate treatment. Hence, it is recommended to the growers and suppliers that these chemicals/preservatives can be used to increase water uptake, enhance opening period of flower, inhibit microorganism populations and enhance vase life of cut roses which ultimately fetch higher price in market. 


\section{AUTHOR'S CONTRIBUTION}

M. M. Aziz: Planed and conducted experiment

S. Rashid: Searched the literature and wrote up manuscript

H. Kousar: Performed statistical analysis

R. Hussain: Reviewed the manuscript

T. Saeed: Performed laboratory analysis

\section{REFERENCES}

Abdel-Kader, H. H., A. M. Hamza, T. T. Elbaz and S. M. Eissa. 2017. Effects of some chemicals on vase life of some cut flowers $i$. Effect of 8-hydroxyquinoline sulfate, silver nitrate, silver nano- particles and chitosan on vase life and quality of cut rose flowers (Rosa hybrid cv. "Black Magic"). Journal of Plant Production, 8 (1): 49 -53.

Awan, M. O., N. Khan, M. Ali, M. Junaid, F. Sohail, R. Nawaz, J. A. Khan, A. Shah, N. Ali, Mehmood, Ziaullah, I. Ahmed and A. U. R. Khalil. 2017. Response of cut rose cv. cardinal to sucrose and $\mathrm{NaOCl}$ concentration. Pure and Applied Biology, 6 (1): 171-179.

Bhattacharjee, S. K. 1999. Evaluation of different types of sugars for improving postharvest life and quality of cut roses. Annals of Agricultural Research, 20 (2): 159-165.

Chamani, A. K., D. C. Joyce, D. E. Irvin, Z. A. Zamani, Y. Mostofi and M. Kafi. 2005. Ethylene and anti-ethylene treatment effects on cut 'First Red' rose. Journal of Applied Horticulture, 1: 3-7.

Chaudhary, G. and A. Khana. 2018. Effects of different concentrations of sucrose on vase life of rose (Rosa sps.cv. Dutch Hybrid). Journal of the Institute of Agriculture and Animal Science, 35: 183-190.

Dineshbabu, M., M. A. N. D. Jawaharlal and M. Vijayakumar. 2002. Influence of holding solutions on the post harvest life of Dendrobium hybrid sonia-17. South Indian Horticulture, 50 (4/6): 451-457.

Elgimabi, E. N. and A. M. Sliai. 2013. Effects of Preservative Solutions on Vase Life and Post-harvest Qualities of Taif Rose Cut Flowers (Rosa damascene cv. Trigintipetala). American Eurasian Journal of Agricultural and Environmental Sciences, 13 (1): 72-80.

Elgimabi, E. L. 2011. Vase life Extension of rose cut flowers (Rose hybrida) as influenced by silver nitrate and sucrose pulsing. American Journal of Agricultural and Biological Science, 6 (1): 128-133.
Hajizadeh, H. S., A. Farokhzad and G. H. Chelan. 2012. Using of preservative solutions to improve post-harvest life of Rosa Hybrid cv. Black magic. Journal of Agricultural Technology, 8 (5): 1801-1810.

Hussen, $\mathrm{S}$ and $\mathrm{H}$. Yassin. 2013. Review on the impact of different vase solutions on the post-harvest life of rose flower. International Journal of Agricultural Research and Review, 1 (2): 13-17.

Ichimura, K., M. Kishimoto, N. Ryo and K. Yoshihiko. 2005. Soluble carbohydrates and variation in vase-life of cut rose cultivars 'Delilah' and 'Sonia'. The Journal of Horticultural Science and Biotechnology, 80: 280-286.

Ichimura, K., M. Taguch and R. Norkoshi. 2006. Extension of the vase life in cut roses by treatment with glucose, isothiazolinonic germicide, citric. Japan Agricultural Research Quarterly, 40: 263-269.

Ichimura, K., Y. Kawabata, M. Kishimito, R. Goto and K. Yamada. 2002. Variation with the cultivar in the vase life of cut rose flowers. Bulletin of National Institute of Floriculture Science, 2: 9-20.

Kalayeh, S. M. O., Y. Mostofi and M. Basirat. 2011. Study on Some Chemical Compounds on the vase life of Two Cultivars of Cut Roses. Journal of Ornamental and Horticultural Plants, 1 (2): 123-128.

Kinfe, B., L. Girmay, R. Yosief, S. Mehari, S. Maekele and G. S. Rao. 2018. Impact of different preservative solutions on extending vase life of Rose (Rosa hybrid) cut flowers. Trends in Biosciences, 11 (29): 3568.

Knee, M. 2000. Selection of biocides for use in floral Pulsing. Journal of Post-harvest Biology and Technology, 18: 227-234.

Liao, L. J., Y. H. Lin, K. L. Huang and W. S. Chen. 2001. Vase life of Eustoma grandiflorum as affected by aluminum sulfate. Botanical Bulletin of Academia Sinica, 42: 35-38.

Macnish, A. J., R. T. Leonard and T. A. Nell. 2008. Treatment with chlorine dioxide extends the vase life of selected cut flowers. Post-harvest Biology and Technology, 50: 197-207.

Mahmoud, I. Y., M. Eldeen and N. E. Elgemaby. 2014. Effect of bactericides and sucrose pulsing on longevity and vase life of rose cut flowers. International Journal of Sciences: Basic and Applied Research, 14 (2): 117129. 
Nigussie, K. 2005. Ornamental Horticulture: A technical material. Jimma University College of Agriculture and Veterinary medicine, Jimma Ethiopia.

Panhwar, F. 2006. Post-harvest technology of fruits and vegetables. ECO Services International, Hyderabad Sindh, Pakistan.

Reezi, S., M., Babalar and K. Kalantari. 2009. Silicon alleviates salt stress, decreases MDA content and affects petal color of salt stressed cut rose (Rosa hybrida L.) 'Hot Lady'. African Journal of Biotechnology, 8: 1502-1508.

Sedaghathoor, S., Z. Narouei, S. A. Sajjadi and S. Piri. 2020. The effect of chemical treatments (silver thiosulfate and putrescine) on vase life and quality of cut Chrysanthemum morifolium (Ram.) flowers. Cogent Biology, 6 (1): 1754320.

Seyf, M., A. Khalighi, Y. Mostofi and R. Naderi. 2012. Study on the effect of aluminum sulfate treatment on post-harvest life of the cut rose 'Boeing' (Rosa hybrid cv. Boeing). Journal of Horticultural sciences and Biotechnology, 16 (3): 128-132.

Sikandar, H., Noorul Amin, A. K. Muhammad, M. A. Tarek, M. Soliman, H. Kashif, A. Imran, R. K. Muhammad and Z. LiangJun. 2012. Impact of silver Thiosulfate and sucrose solution on the vase life of rose cut flower Cv. Cardinal. Advances in Environmental Biology, 6 (5): 1643-1649.

Singh, A. K. and A. K. Tiwari. 2002. Effect of pulsing on post-harvest life of Rose cv. Doris
Tystermann. South Indian Horticulture, 50 (2): 140-144.

Skutnik, E., J. R. Swider, A. J. Edrzejuk and A. Łukaszewska. 2020. The effect of long-term cold storage and preservatives on senescence of cut herbaceous peony flowers. Agronomy, 10: 1631.

Stewel, R. G. D., J. H. Torrie and D. A. Dickey. 1997. Principles and procedures of statistics: A biometrical approach $\left(3^{\text {rd }}\right.$ Ed.). McGraw- Hill, New York.

Sudaira, M. A., A. Uthairatanakij and H. T. Nguyen. 2017. Post-harvest quality effects of different vase life solutions on cut rose (Rosa hybrid L.). International Journal of Agriculture, Forestry and Life Science, 1 (1): 12-20.

Suong, T. H., I. Byung-Chun., W. C. Hyung, J. Yeon-Ok and L. Jin-Hee. 2017. Assessment of pretreatment solutions for improving the vase life and post-harvest quality of cut roses (Rosa hybrida L. 'Jinny'). Flower Research Journal, 25 (3): 101-109.

Tsegaw, T., S. Tilahun and G. Humphries. 2011. Influence of pulsing biocides and preservative solution treatment on the vase life of cut rose (Rosa hybrid L.) varieties. Journal of Applied Science and Technology, $2(2): 1-18$.

Zamani, S., M. Kazemi and M. Aran. 2011. Postharvest life of cut rose flowers as affected by salicylic acid and glutamine. World Applied Science Journal, 12 (9): 1621-1624.

(Received: April 11, 2021; Accepted: November 09, 2021) 